\section{Effect of Calcium lons on the Release of Acetylcholine from the Cerebral Cortex}

THE presence of calcium ions $\left(\mathrm{Ca}^{2+}\right)$ in the external medium is essential for the release of acetylcholine (ACh) at peripheral synapses (superior cervical ganglion, neuromuscular junction $)^{1-6}$. Evidence now suggests that $\mathrm{ACh}$ is a transmitter in the cerebral cortex, and several investigators have shown that this substance is continuously released from the cerebral cortex in amounts which can be directly related to the level of cortical activity ${ }^{7-12}$. This communication describes how changes in local $\mathrm{Ca}^{2+}$ affect the spontaneous and evoked release of $\mathrm{ACh}$ from the cat cerebral cortex. $d$-tubocurarine chloride $\left(10^{-5} \mathrm{~g} / \mathrm{ml}\right.$, California Biochemical Corporation). This procedure abolished the response to standard solutions of ACh, as well as to the active principle present in the samples. The results were analysed statistically by using Student's $t$ test.

When the normal Ringer-Locke solution was changed for one containing no calcium chloride, there was a significant fall (of 34 per cent on average) in the amount of ACh collected from the surface of the cerebral cortex in the absence of peripheral stimulation (Table 1). The depressant effect of the lack of $\mathrm{Ca}^{2+}$ was readily reversed by restoring $\mathrm{Ca}^{2+}$ to the collection fluid. It is interesting that the action of $\mathrm{Ca}^{2+}$ is exerted only on a portion of the spontaneous release of $\mathrm{ACh}$, while the remaining fraction Table 1. MEaN RATE OF ACETYlcholine RELEASE (ng/min/em²) FroM UNSTIMULATED CEREBRAL CORTEX INTO RINGER-LOCKE SOLUTION CONTAINING

\begin{tabular}{|c|c|c|c|c|c|c|}
\hline Region & No. of cats & Rate in 2 mmolar & Rate in 1 mmolar & Rate in 0.2 mmolar & Rate in 0 mmolar & $P$ \\
\hline $\begin{array}{l}\text { Sensory-motor and parietal } \\
\text { cortex }\end{array}$ & $\left\{\begin{aligned} 12 \\
2\end{aligned}\right.$ & $\begin{array}{l}0.74 \pm 0.09 \text { (S.E.) } \\
0.90 \pm 0.20\end{array}$ & $0 \cdot 81 \pm 0 \cdot 19$ & $=$ & $0 \cdot 49 \pm 0 \cdot 06$ & $<\underset{*}{*}+05$ \\
\hline Sensory-motor cortex & 4 & $0.48 \pm 0.12$ & - & $0 \cdot 36 \pm 0.07$ & - & \\
\hline
\end{tabular}

cortex

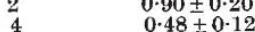

* These data are of a preliminary nature, but they sugg rate of release of ACh as compared with the control values.

Experiments were performed on cats anaesthetized with a mixture of diallyl-barbituric acid and urethane ('Dial', Ciba, Ltd.) given intraperitoneally $(0.7-0.8 \mathrm{ml} . / \mathrm{kg}) . \mathrm{ACh}$ was collected from the exposed surface $\left(1 \mathrm{~cm}^{2}\right)$ of the pericruciate and suprasylvian cortex, using the 'Perspex' chamber technique described before? The chambers were filled with $1 \mathrm{ml}$. of Ringer-Locke solution containing eserine sulphate $\left(1 \times 10^{-4} \mathrm{~g} / \mathrm{ml}\right.$., British Drug Houses $)$ and aerated with 5 per cent carbon dioxide in oxygen. The Ringer-Locke solution used had the following ionic composition: $137.0 \mathrm{mmolar}$ sodium chloride; 2.5 mmolar potassium chloride; $2.0 \mathrm{mmolar}$ calcium chloride; 1.0 mmolar magnesium chloride; 1 mmolar sodium phosphate; 12.0 mmolar sodium bicarbonate; and 11.0 mmolar glucose. was unaffected by the absence of calcium. This result is qualitatively in agreement with the data obtained at mammalian motor nerve terminals ${ }^{4-6}$.

Mitehell $^{8}$ has reported that electrical stimulation of a peripheral sensory nerve produced an increase in the rate at which ACh was liberated from the surface of the contralateral sensory cortex. Using this procedure we have found that with 0.2 mmolar $\mathrm{Ca}^{2+}$ and with $\mathrm{Ca}^{2+}$-free solutions there is no increase in the output of ACh during peripheral stimulation (Table 2 ). These results are of interest, because in all synapses so far examined the release of the chemical transmitter by the nerve impulse requires the presence of $\mathrm{Ca}^{2+}$ in the external medium. It seems that the cerebral cortex is not an exception to this. These observations also provide supporting evidence for the

Table 2. MEAN RATE OF SPONTANEOUS AND EVOKED ACETYLCHOLINE RELEASE (ng/min/cm²) FROM CEREBRAL CORTEX INTO RINGER-LOCKE SOLUTION CONTAINING DIFFERENT CONCENTRATIONS OF $\mathrm{Ca}^{2+}$

$\begin{array}{ccc}\text { Region } & \text { No. of cats } & {\left[\mathrm{Ca}^{2+}\right]} \\ \text { Sensory-motor cortex } & \left\{\begin{array}{l}8 \\ 8\end{array}\right. & 2 \text { mmolar } \\ 0 \cdot 2 \pm 0 \text { mmolar }\end{array}$

The concentration of $\mathrm{Ca}^{2+}$ was varied in different experiments $\left(\mathrm{Ca}^{2+}\right.$-free, $0 \cdot 2,1 \cdot 0$ and $2 \cdot 0$ mmolar $)$ by omitting calcium chloride; the other ions and the concentration of eserine remained constant. The small changes in osmolarity were not corrected for. The stimulating pulses were usually rectangular pulses lasting $1 \mathrm{msec}$, delivered at a frequency of $0.5 / \mathrm{sec}$ to the contralateral forepaw, through a radio-frequency isolation unit of the Grass ' $S 8$ ' stimulator. Efficiency of stimulation was checked by recording the evoked potential with a cathode-ray oscilloscope. ACh was sampled from the surface of the cerebral cortex unilaterally for between fifteen and eighteen collection periods, each of $15 \mathrm{~min}$ duration. The usual procedure was as follows: two resting samples alternated with a stimulated one, first with normal $\left(2 \cdot 0\right.$ mmolar $\left.\mathrm{Ca}^{2+}\right)$ Ringer-Locke and then the sequence was repeated with low- $\mathrm{Ca}^{2+}$ or $\mathrm{Ca}^{2+}$-free solution. In this way, we were able to detect a significant change in the release of $\mathrm{ACh}$, which was reproducible. Immediately after removal, samples were frozen at $-15^{\circ} \mathrm{C}$ and stored at that tem. perature.

Bio-assays were performed within $48 \mathrm{~h}$ of collection on the dorsal muscle of the leech (Hirudo medicinalis). As a control, muscle was soaked for $10 \mathrm{~min}$ in a solution of

Resting rate
$\begin{aligned} & 0.54 \pm 0 \cdot 09 \\ & 0.39 \pm 0.05\end{aligned}$

$\begin{gathered}\text { Rate on contralateral } \\ \text { forepaw stimulation }\end{gathered}$
$0 \cdot 81 \pm 0 \cdot 09$
$0 \cdot 42 \pm 0.05$

$\boldsymbol{P}$

$<0.05$

Not significant

involvement of ACh as a synaptic transmitter in the cerebral cortex.

We thank Professor K. Krnjević and Dr D. W. Straughan for their help and the Wellcome Trust for a grant.

M. RANDIĆ

A. PADJEN

Biology Division, Institute "Rudjer Boškovič", and Department of Pharmacology,

Medical Faculty,

University of Zagreb.

Received February 20, 1967.

${ }^{1}$ Harvey, A. M., and MacIntosh, F. C., J. Physiol., 97, 408 (1940).

${ }^{2}$ Hutter, O. F., and Kostial, K., J. Physiol., 124, 234 (1954),

${ }^{3}$ Del Castillo, J., and Stark, L., J. Physiol., 116, 507 (1952).

4 Hubbard, J. I., J. Physiol., 159, 507 (1961).

5 Feldman, D. S., J. Physiol. 179, 33P (1965).

- Elmqvist, D., and Feldman, D. S., J. Physiol., 181, 487 (1965).

"MacIntosh, F. C., and Oborin, P. E., Abstract of Nineteenth Intern. Physiol. Cong., 580 (1953).

${ }^{8}$ Mitchell, J. F., J. Physiol., 165, 98 (1963).

Kanai, T., and Szerb, J. C., Nature, 205, 80 (1965).

10 Phillis, J. W., and Chong, G. C., Nature, 207, 1253 (1965).

$"$ Collier, B., and Mitchell, J. F., J. Physiol., 184, 239 (1966).

12 Celesia, G. G., and Jasper, H. H., Neurology, 16, 1053 (1966). 